\title{
Efektivitas Re-Cycle Polinasi Melalui Teknik Pemangkasan dan Dosis Pupuk NPK Terhadap Produksi dan Mutu Benih Terung (Solanum melongena L.)
}

\author{
Author(s): Fatimatus Sahro*(1); Dwi Rahmawati ${ }^{(1)}$; Suharjono $^{(1)}$ \\ (1) Program Studi Teknik Produksi Benih, Jurusan Produksi Pertanian, Politeknik Negeri Jember \\ * Corresponding author: zahro476@gmail.com
}

\begin{abstract}
ABSTRAK
Penelitian ini bertujuan untuk mengetahui produksi dan mutu benih terung menggunakan teknologi Re-cycle polinasi melalui teknik pemangkasan dan dosis pupuk NPK. Penelitian ini dilakukan pada bulan Maret sampai Desember 2016 di Desa Jatiagung, Kabupaten Jember. Rancangan percobaan yang digunakan adalah Rancangan Acak Kelompok (RAK) Faktorial. Faktor pertama adalah teknik pemangkasan dengan menyisakan 2 ruas di atas cabang Y (T1) dan pemangkasan dengan menyisakan 3 ruas di atas cabang Y (T2). Faktor kedua adalah dosis pupuk NPK: $120 \mathrm{~g} / \operatorname{tanaman}$ (P1) 170 $\mathrm{g} / \operatorname{tanaman}(\mathrm{P} 2)$, dan $220 \mathrm{~g} / \operatorname{tanaman}(\mathrm{P} 3)$. Parameter pengamatan yang diamati adalah jumlah tunas, umur berbunga saat $80 \%$, umur panen saat $80 \%$, jumlah buah, jumlah biji bernas per buah, jumlah biji hampa per buah, jumlah biji per buah, produksi benih per hektar, uji daya kecambah benih, keserempakan tumbuh benih dan kecepatan tumbuh benih. Hasil penelitian menunjukkan bahwa perlakuan teknik pemangkasan hanya memberikan pengaruh nyata terhadap jumlah tunas. Pemangkasan dengan menyisakan 3 ruas diatas cabang Y (T2) menghasilkan 11,83 tunas. Perlakuan dosis pupuk NPK memberikan pengaruh nyata $(*)$ terhadap parameter jumlah buah, bobot 1000 butir dan produksi benih per hektar, serta memberikan pengaruh yang sangat nyata (**) pada parameter pengamatan jumlah tunas, umur berbunga $80 \%$, umur panen $80 \%$, jumlah biji hampa perbuah dan daya kecambah benih. Dosis pupuk NPK 170 g/tanaman (P2) menghasilkan produksi tetinggi yaitu $2,7148 \mathrm{kw} / \mathrm{ha}$. Secara bersama-sama dua perlakuan yang diberikan tidak berpengaruh nyata pada semua parameter yang diamati.
\end{abstract}

\author{
Kata Kunci: \\ Dosis pupuk \\ NPK; \\ Teknik \\ pemangkasan; \\ Re-cycle \\ polinasi;
}

\begin{abstract}
Keywords: $\quad$ This research aims to know production and quality eggplant with applied Re-cycle pollination technology from pruning technique and doses NPK fertilizer. This research

Doses of NPK held from March to December 2016 in Jatiagung village, Gumukmas, Jember. The

Fertilizer; research design used a Randomized Block Design (RBD) Factorial with 2 factors. The

Pruning

Technique;

Re-cycle

Polination; first factor was pruning technique consist of leaving 2 segments on branch Y (T1) and pruning leaving 3 segments on branch $Y(T 2)$. The second factor was doses NPK fertilizer consists of $120 \mathrm{~g} /$ plant (P1), $170 \mathrm{~g} /$ plant (P2), $220 \mathrm{~g} /$ plant (P3). Observed parameters were total buds, age at $80 \%$ flowering, age at $80 \%$ harvested, total fruit, total seed, a total of pithy seed, a total of empty seed, production per hectare, germination capacity, germination quality, and seed germination rate. The result from this research showed that pruning technique was only giving a significant effect on the total number of buds. Pruning with leaving 3 segments on branch Y(T2) resulted in 11,83 buds. The treatments of doses NPK fertilizer gave a significant effect $\left(^{*}\right)$ on the parameter of total fruit, weight of 1000 seeds, and seed production per hectare and given a very significant effect (**) on parameter of total number of buds, age at $80 \%$ flowering, age at $80 \%$ harvested, total empty seed per fruit, and germination capacity. Doses of NPK fertilizer 170 g/plant (P2) has a higher resulted is $2,7148 \mathrm{kw} / \mathrm{ha}$. Togetherness the two treatments were showed not a significant effect to all the observed parameters.
\end{abstract}




\section{PENDAHULUAN}

Tanaman terung (Solanum melongena L.) adalah tanaman hortikultura yang sudah banyak tersebar di Indonesia. Terung biasanya dikonsumsi dengan mengolahnya menjadi sayur, digoreng atau dimakan mentah sebagai lalapan. Terung memiliki kandungan gizi yang cukup tinggi seperti protein, lemak, karbohidrat, kalsium, fosfor, besi dan vitamin (Soetasad $\&$ Muryanti, 2000). Tingginya kandungan gizi yang terdapat didalam terung menjadikan terung sebagai sayuran yang disukai masyarakat. Menurut Direktorat Jenderal Hortikultura, (2015) produksi terung nasional dalam lima tahun terakhir tidak stabil. Ketidakstabilan peningkatan produksi terung dapat disebabkan oleh beberapa faktor misalnya, benih yang digunakan dan kurangnya penerapan teknologi. Penerapan teknologi yang kurang tepat menjadi salah satu kendala di dalam upaya peningkatan produksi terung, oleh karena itu penggunaan teknologi yang tepat harus terus diupayakan sehingga produksi terung stabil.

Salah satu hasil teknologi melalui penelitian adalah penggunaan benih bermutu. Benih bermutu menjadi salah satu faktor yang dapat berpengaruh terhadap kegiatan produksi pertanian dan memegang peranan penting dalam menunjang keberhasilan pertanian Indonesia. Penggunaan benih bermutu akan menjamin peningkatan kualitas hasil panen. Hal ini sesuai dengan pendapat Sutopo (2002), yang mengatakan bahwa benih harus memiliki mutu yang tinggi sehingga benih mampu menghasilkan tanaman yang berproduksi maksimum dengan penerapan teknologi maju.

Ketersediaan benih bermutu harus terus diupayakan melalui berbagai penelitian sehingga tercipta inovasi baru. Re-cycle polinasi (Polinasi Kedua) merupakan salah satu hasil inovasi di bidang pertanian dalam rangka meningkatkan produksi dan mutu benih.
Re-cycle polinasi melalui teknik pemangkasan peremajaan bertujuan untuk menumbuhkan tunas baru.

Peremajaan pada tanaman dapat dilakukan melalui penanaman bibit baru atau dapat juga melalui pemangkasan pada bagian cabang atau batang yang tidak produktif kemudian diikuti perawatan tunas anakan yang baru tumbuh. Setelah tunas baru tumbuh Re-cycle polinasi dapat dilakukan pada fase generatif. Teknologi ini dapat meningkatkan indeks panen 2 kali dengan 1 kali penanaman. Re-cycle polinasi pada tanaman terung merupakan proses polinasi tahap kedua yang dilakukan setelah tanaman sisa panen dipangkas, sehingga tanaman terung menghasilkan tunas baru dan dapat dilakukan Re-cycle polinasi pada fase generatifnya.

Keberhasilan Re-cycle polinasi tanaman terung dipengaruhi oleh teknik pemangkasan, karena sebelum dilakukan Re-cycle polinasi tanaman terung terlebih dahulu dipangkas untuk peremajaan. Pemangkasan peremajaan berkaitan dengan ruas tanaman yang tersisa, dimana setiap ruas tanaman terdapat tunas lateral yang dapat menghasilkan tunas baru. Seran (2016) menyatakan bahwa pemangkasan tunas lateral dan mempengaruhi diameter batang dan buah per tanaman,

Re-cycle polinasi juga dipengaruhi oleh unsur hara tambahan seperti unsur N, $\mathrm{P}$ dan K. Ketiga unsur hara tersebut saling berinteraksi satu sama lain dalam menunjang pertumbuhan tanaman. Pupuk NPK merupakan pupuk dengan unsur hara yang kompleks karena pupuk tersebut mengandung unsur hara $\mathrm{N}, \mathrm{P}$ dan $\mathrm{K}$, dimana unsur $\mathrm{N}$ dapat memacu pertumbuhan vegetatif tanaman seperti pertumbuhan tunas, unsur $\mathrm{P}$ berperan dalam pembentukan bunga, buah dan biji, sedangkan unsur $\mathrm{K}$ berperan dalam memperkuat tegaknya batang dan membuat biji tanaman menjadi lebih padat berisi. Aplikasi pupuk NPK $10 \mathrm{~g} /$ tanaman merupakan kombinasi perlakuan terbaik 
untuk pertumbuhan tanaman nanasdengan sumber tunas batang (Cahyono et al., 2014). Penggunaan dosis pupuk NPK setiap tanaman berbeda, sehingga diperlukan dosis yang tepat dalam peningkatan produksi dan mutu benih terung.

\section{BAHAN DAN METODE}

Penelitian ini dilaksanakan pada bulan Maret hingga Desember 2016 di Desa Jatiagung, Kecamatan Gumuk Mas, Kabupaten Jember dan di Laboratorium Teknik Produksi Benih, Politeknik Negeri Jember, Kabupaten Jember.

Alat yang digunakan antara lain, cangkul, sabit, sprayer, roll meter, timbangan, selang polinasi, pinset, staples, dan saringan. Bahan yang digunakan antara lain, benih terung, pupuk, pestisida, sungkup, benang warna, dan label.

Rancangan percobaan yang digunakan adalah Rancangan Acak Kelompok Faktorial (RAKF) dengan 2 faktor dan 4 ulangan. Faktor utama adalah teknik pemangkasan $(\mathrm{T})$ yang terdiri dari 2 taraf, $\mathrm{T}_{1}=$ teknik pemangkasan dengan menyisakan 2 ruas di atas cabang $\mathrm{Y}, \mathrm{T}_{2}=$ teknik pemangkasan dengan menyisakan 3 ruas di atas cabang Y. Faktor kedua dosis pupuk NPK $(\mathrm{P})$, yang terdiri dari 3 taraf, $\mathrm{P}_{1}$ $=$ dosis pupuk NPK $120 \mathrm{~g} /$ tanaman, $\mathrm{P}_{2}=$ dosis pupuk NPK $170 \mathrm{~g} /$ tanaman, $\mathrm{P}_{3}=$ dosis pupuk NPK $220 \mathrm{~g} /$ tanaman. Data analisis menggunakan uji $\mathrm{F}$ (ANOVA) dan dilanjutkan dengan Uji BNT pada taraf $\alpha=$ $5 \%$.

Prosedur pelaksanaan meliputi analisis tanah, pengolahan lahan, persemaian benih, penanaman, pemupukan, pemangkasan, persiapan alat dan bahan hibridisasi atau polinasi, emaskulasi, hibridisasi, pemeliharaan, panen, ekstraksi dan pengujian mutu benih.

Parameter pengamatan meliputi jumlah tunas, umur berbunga dan umur panen saat $80 \%$, jumlah buah per tanaman, jumlah biji per buah, jumlah biji bernas, jumlah biji hampa, produksi per hektar, daya berkecambah, keserempakan dan kecepatan tumbuh benih.

\section{HASIL DAN PEMBAHASAN}

Re-cycle polinasi merupakan polinasi tahap kedua yang dilakukan pada tanaman sisa panen yang telah dipangkas untuk peremajaan, sehingga tanaman tumbuh normal kembali dan dapat dilakukan polinasi kedua. Penerapan Recycle polinasi bertujuan untuk meningkatkan hasil produksi dalam satu kali tanam.

Hasil pengamatan karakter tanaman utama pada fase vegetatif, generatif dan uji mutu benih dijabarkan dalam setiap parameter pengamatan.

\section{Jumlah Tunas Tanaman Terung Re- cycle Polinasi}

Berdasarkan Tabel 1 pengaruh teknik pemangkasan 3 ruas di atas cabang $\mathrm{Y}\left(\mathrm{T}_{2}\right)$ menghasilkan jumlah tunas terbanyak yaitu 11,83 tunas. Hal ini diduga pemangkasan dapat memacu pertumbuhan tunas. Menurut (Raden et al., 2009) bahwa pemangkasan batang utama dapat

Tabel 1. Rerata Jumlah Tunas pada Perlakuan Teknik Pemangkasan

\begin{tabular}{ll}
\hline Perlakuan & $\begin{array}{l}\text { Jumlah } \\
\text { Tunas }\end{array}$ \\
Pemangkasan & $10,83 \mathrm{a}$ \\
2 ruas di atas cabang & $11,83 \mathrm{~b}$ \\
\hline ruas di atas cabang & 0,93 \\
\hline Nilai BNT \% &
\end{tabular}

Keterangan :

Angka-angka yang diikuti oleh huruf yang berbeda menunjukkan berbedan yata pada uji BNT 5\%.

meningkatkan jumlah cabang primer pada tanaman jarak pagar. Teknik pemangkasan berkaitan dengan ruas tanaman yang tersisa, dimana setiap ruas tanaman terdapat tunas lateral yang dapat menghasilkan tunas baru. Semakin banyak ruas tanaman yang tersisa, maka semakin banyak pula tunas baru yang tumbuh. Sehingga teknik pemangkasan pada 
perlakuan 3 ruas di atas cabang $\mathrm{Y}\left(\mathrm{T}_{2}\right)$ diduga dapat menghasilkan jumlah tunas yang lebih banyak. Hal ini sejalan dengan pendapat Putri et al., (2009) yang menyatakan bahwa pemangkasan cabang pada tanaman jarak pagar dengan pemeliharaan 3 cabang primer atau lebih dapat meningkatkan jumlah cabang sekunder.

Tabel 2. Rerata Jumlah Tunas dengan Perlakuan Dosis Pupuk NPK

\begin{tabular}{ll}
\hline Dosis NPK & Jumlah Tunas \\
\hline $120 \mathrm{~g} /$ tanaman & $10,38 \mathrm{a}$ \\
$170 \mathrm{~g} / \operatorname{tanaman}$ & $11,38 \mathrm{ab}$ \\
$220 \mathrm{~g} /$ tanaman & $12,38 \mathrm{~b}$ \\
\hline Nilai BNT $\%$ & 1,14 \\
\hline
\end{tabular}

Keterangan :

Angka-angka yang diikuti oleh huruf yang berbeda menunjukkan berbeda nyata pada uji BNT 5\%.

Berdasarkan Tabel 2 perlakuan dosis pemupukan NPK 220 g/tanaman $\left(\mathrm{P}_{3}\right)$ menunjukkan jumlah tunas terbanyak yaitu 12,38 tunas. Hal ini diduga dosis pupuk NPK dapat memacu pertumbuhan tunas tanaman terung, karena didalam pupuk NPK terdapat unsur nitrogenyang berperan dalam pertumbuhan vegetatif tanaman. (Feleafel \& Mirdad, 2013) menyatakan bahwa unsur $\mathrm{N}$ dapat memicu pertumbuhan pada tanaman terong seperti pertumbuhan tunas, tinggi tanaman, jumlah anakan dan jumlah cabang.

\section{Umur Berbunga Tanaman Terung Re- cycle Polinasi}

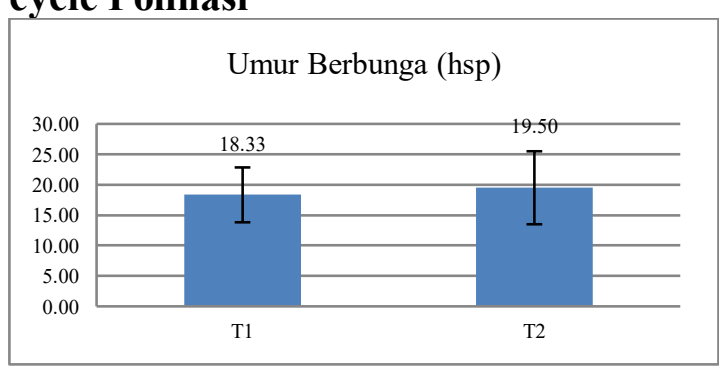

Gambar 1. Rerata Umur Berbunga pada Perlakuan Teknik Pemangkasan
Berdasarkan Gambar 1 perlakuan pemangkasan dengan menyisakan 2 ruas di atas cabang $\mathrm{Y} \quad\left(\mathrm{T}_{2}\right)$ cenderung menghasilkan umur berbunga lebih cepat. Namun, secara umum perlakuan teknik pemangkasan memberikan pengaruh berbeda tidak nyata terhadap parameter umur berbunga. Hal tersebut diduga umur berbunga pada tanaman terung lebih dipengaruhi oleh faktor genetik dari tanaman. Menurut Darjanto and Satifah, (1984), pembentukan bunga adalah peralihan dari fase vegetatif ke fase generatif. Peralihan dari fase vegetatif ke generatif dapat dipengaruhi oleh faktor genetik dan faktor lingkungan seperti suhu, cahaya kelembaban dan unsur hara.

Perlakuan dosis pupuk NPK 220 $\mathrm{g} /$ tanaman menunjukkan umur berbunga paling cepat dan dosis pupuk NPK 120 g/tanaman menunjukkan umur berbunga paling lambat. Hal ini diduga dosis pupuk NPK mempercepat keluarnya bunga tanaman terung, karena didalam pupuk NPK terdapat unsur fosfor, yang mana unsur fosfor sangat berperan dalam proses pembungaan. Rina (2015) menyatakan bahwa unsur $\mathrm{P}$ (fosfor) dapat memacu pembentukan bunga dan pematangan buah atau biji, sehingga mempercepat umur panen.

Tabel 3. Rerata Umur Berbunga Saat $80 \%$ pada Perlakuan Dosis Pupuk NPK

\begin{tabular}{ll}
\hline Dosis NPK & $\begin{array}{l}\text { Umur Berbunga } \\
\text { Saat } 80 \%\end{array}$ \\
\hline $120 \mathrm{~g} /$ tanaman & $20,25 \mathrm{a}$ \\
$170 \mathrm{~g} /$ tanaman & $18,88 \mathrm{ab}$ \\
$220 \mathrm{~g} /$ tanaman & $17,63 \mathrm{~b}$ \\
\hline Nilai BNT $\%$ & 1,14
\end{tabular}

Keterangan :

Angka-angka yang diikuti oleh huruf yang berbeda menunjukkan berbedan yata pada uji BNT 5\%. 
Umur Panen Tanaman Terung Re-cycle Polinasi

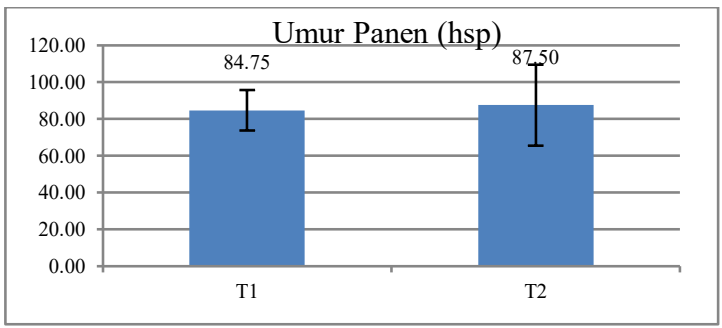

Gambar 2. Rerata Umur Panen pada Perlakuan Teknik Pemangkasan

Berdasarkan Gambar 2 perlakuan teknik pemangkasan dengan menyisakan dua ruas di atas cabang $\mathrm{Y}\left(\mathrm{T}_{1}\right)$ cenderung menghasilkan umur panen lebih cepat yaitu 84,75 hari setelah pangkas. Namun, secara umum perlakuan teknik pemangkasan memberikan pengaruh berbeda tidak nyata terhadap parameter umur panen. Hal tersebut diduga umur panen tanaman terung dipengaruhi oleh sifat genetik dari setiap varietas. (Bukhari, 2013) menyatakan bahwa umur panen tanaman terung tergantung sifat genetis dari setiap varietasnya.

Tabel 4. Rerata Umur Panen Saat 80\% pada Perlakuan Dosis Pupuk NPK

\begin{tabular}{ll}
\hline Dosis NPK & Umur Panen Saat $80 \%$ \\
\hline $120 \mathrm{~g} / \operatorname{tanaman}$ & $90,25 \mathrm{a}$ \\
$170 \mathrm{~g} / \operatorname{tanaman}$ & $86,13 \mathrm{~b}$ \\
$220 \mathrm{~g} / \operatorname{tanaman}$ & $82,00 \mathrm{c}$ \\
\hline Nilai BNT \% & \multicolumn{2}{c}{4,90} \\
\hline
\end{tabular}

Keterangan :

Angka-angka yang diikuti oleh huruf yang berbeda menunjukkan berbedan yata pada uji BNT 5\%.

Berdasarkan Tabel 4 perlakuan dosis pupuk NPK $220 \mathrm{~g} /$ tanaman menghasilkan umur panen lebih cepat yaitu 82 hari setelah pangkas. Hal ini diduga kebutuhan tanaman akan unsur fosfor dapat terpenuhi dengan penggunaan pupuk NPK 220 $\mathrm{g} /$ tanaman, seperti yang kita ketahui bahwa unsur hara fosfor dapat mempercepat pembungaan dan pemasakan buah. Lingga and Marsono, (2010) menyatakan bahwa unsur fosfor (P) berfungsi untuk mempercepat pembungaan, pemasakan biji dan pemasakan buah.

Jumlah Buah Tanaman Terung Recycle Polinasi

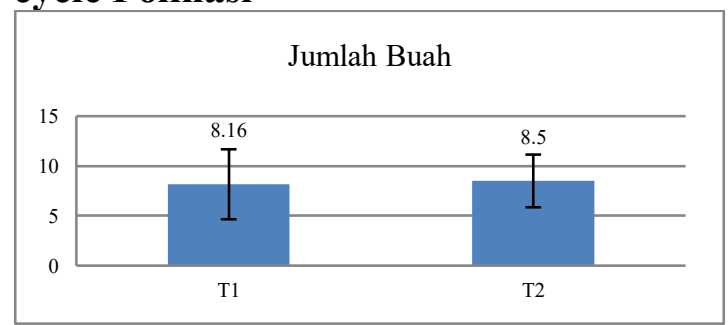

Gambar 3. Rerata Jumlah Buah pada Perlakuan Teknik Pemangkasan

Berdasarkan Gambar 3 teknik pemangkasan 3 ruas di atas cabang $\mathrm{Y}\left(\mathrm{T}_{2}\right)$ cenderung menghasilkan jumlah buah lebih banyak yaitu 8,5 buah. Namun secara umum perlakuan teknik pemangkasan tidak berpengaruh terhadap parameter pengamatan jumlah buah. Hal ini diduga karena terbentuknya buah lebih dipengaruhi oleh tingkat keberhasilan dalam polinasi. Salah satu faktor yang mempengaruhi keberhasilan polinasi yaitu kondisi serbuk sari dan putik. Darjanto \& Satifah, (1984) menjelaskan bahwa pembuahan akan berlangsung optimal jika serbuksari atau pollen dan kepala putik dalam keadaan fertil.

Tabel 5. Rerata Jumlah Buah dengan Perlakuan Dosis Pupuk NPK

\begin{tabular}{ll}
\hline Dosis NPK & Jumlah Buah \\
\hline $120 \mathrm{~g} /$ tanaman & $7,50 \mathrm{a}$ \\
$170 \mathrm{~g} /$ tanaman & $9,00 \mathrm{ab}$ \\
$220 \mathrm{~g} /$ tanaman & $8,50 \mathrm{~b}$ \\
\hline Nilai BNT \% & 1,10 \\
\hline
\end{tabular}

Keterangan :

Angka-angka yang diikuti oleh huruf yang berbeda menunjukkan berbedan yata pada uji BNT 5\%.

Berdasarkan Tabel 5 perlakuan dosis pemupukan NPK 170 g/tanaman $\left(\mathrm{P}_{2}\right)$ menghasilkan jumlah buah tertinggi yaitu 9 
buah. Hal ini diduga karena perlakuan pupuk NPK dosis 170 g/tanaman merupakan dosis yang optimal bagi tanaman, sehingga dapat menyediakan sejumlah unsur hara untuk pembentukan putik yang merupakan medium perkecambahan dan pertumbuhan serbuk sari saat pembentukan buah. (Pujisiswanto \& Pangaribuan, 2008) menyatakan bahwa pembentukan dan pengisian buah dapat dipengaruhi oleh ketersedian unsur hara untuk berlangsungnya proses fotosintesis yang menghasilkan karbohidrat, lemak, protein, mineral dan vitamin yang kemudian ditranslokasikan kebagian penyimpanan seperti buah.

Jumlah Biji, Jumlah Biji Bernas dan Jumlah Biji Hampa Tanaman Terung Re-cycle Polinasi

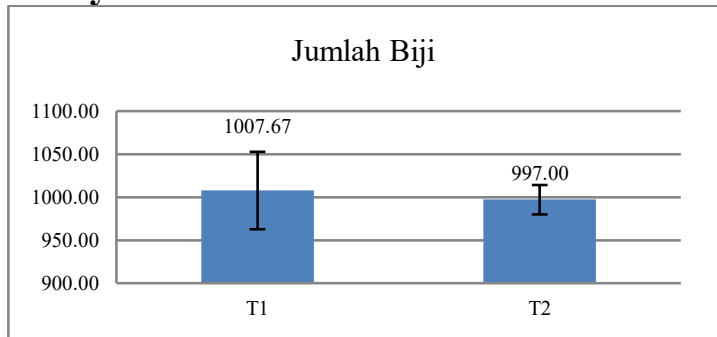

Gambar 4. Rerata Jumlah Biji Perbuah pada Perlakuan Teknik Pemangkasan

Berdasarkan Gambar 4 teknik pemangkasan dengan menyisakan 2 ruas di atas cabang $\mathrm{Y} \quad\left(\mathrm{T}_{1}\right)$ cenderung menghasilkan jumlah biji paling tinggi yaitu 1007,67 butir. Namun, secara umum perlakuan teknik pemangkasan memberikan pengaruh berbeda tidak nyata terhadap parameter jumlah biji. Hal ini diduga pengisian biji tanaman terung Recycle polinasi tidak dipengaruhi oleh teknik pemangkasan tetapi dipengaruhi oleh faktor lain seperti faktor genetik dan lingkungan. Seperti yang disampaikan Gardner et al., (1988) bahwa pembungaan dan pembuahan serta pengisian biji merupakan peristiwa penting dalam produksi tanaman budidaya. Proses tersebut dapat dipengaruhi oleh faktor lingkungan dan faktor genetik terutama pertumbuhan dan hasil fotosintesis. Faktor genetik berkaitan dengan kemampuan tanaman terung dalam mengoptimalkan produksi dalam pengaturan pengisian biji dengan mengalokasikan hasil fotosintesis secara tepat, sedangkan faktor lingkungan berhubungan dengan proses fotosintesis yaitu penyerapan unsur hara, air dan cahaya.

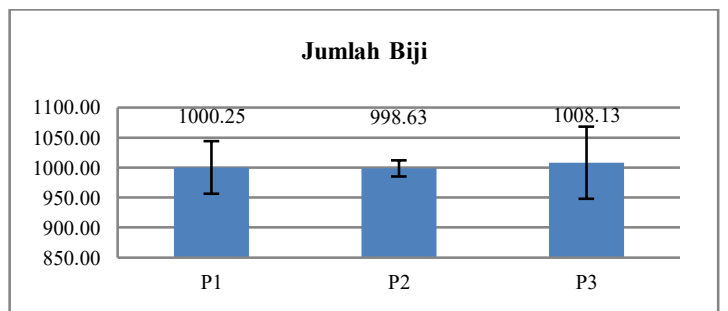

Gambar 5. Rerata Jumlah Biji Per buah pada Perlakuan Dosis Pupuk NPK

Berdasarkan Gambar 5 perlakuan dosis pupuk NPK $220 \mathrm{~g} /$ tanaman $\left(\mathrm{P}_{3}\right)$ cenderung menghasilkan jumlah biji paling tinggi. Namun, secara umum dosis pupuk NPK memberikan pengaruh berbeda tidak nyata terhadap parameter jumlah biji. Hal tersebut diduga jumlah biji tanaman terung Re-cycle polinasi tidak dipengaruhi oleh dosis pupuk NPK, tetapi dipengaruhi oleh faktor lain seperti faktor lingkungan.Saat memasuki fase berbunga, curah hujan di lingkungan penelitian sangat tinggi sehingga menghambat proses polinasi atau penyerbukan yang menyebabkan pembentukan biji tidak optimal. Astuti, (2010) menyatakan bahwa proses penyerbukan dapat terganggu oleh intensitas curah hujan yang tinggi, sehingga dapat mengurangi hasil atau produksi tanaman. 


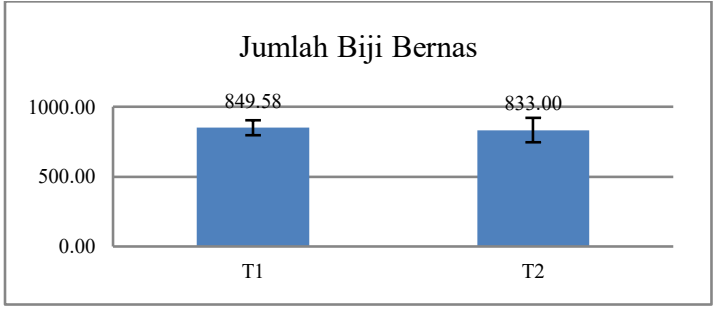

Gambar 6. Rerata Jumlah Biji Bernas Per Buah Perlakuan Teknik Pemangkasan

Berdasarkan Gambar 6 perlakuan teknik pemangkasan dengan menyisakan 2 ruas di atas cabang $\mathrm{Y}\left(\mathrm{T}_{1}\right)$ cenderung menghasilkan jumlah biji bernas paling tinggi yaitu 849,58 butir per buah. Namun, secara umum perlakuan teknik pemangkasan memberikan pengaruh berbeda tidak nyata terhadap parameter jumlah biji bernas per buah. Hal ini diduga jumlah biji bernas setiap buah dipengaruhi oleh tingkat keberhasilan dalam proses pembuahan. Pada proses pembuahan, pollen yang jatuh atau menempel pada kepala putik akan tumbuh dan memanjang hingga bertemu dengan indung telur, yang kemudian menghasilkan lembaga atau endosperm. Endosperm merupakan cadangan makanan hasil peleburan antara inti sel sperma dan 2 sel inti polar pada saat pembentukan biji di embryo sach.

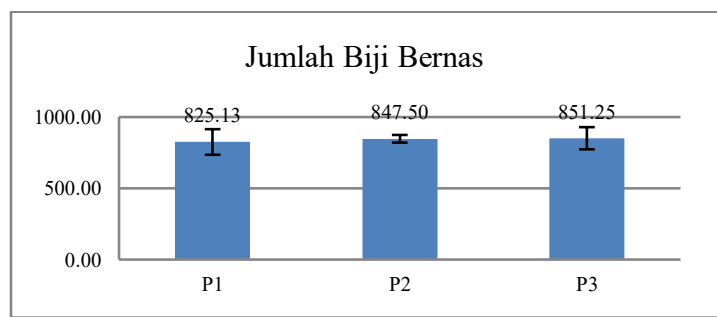

Gambar 7. Rerata Jumlah Biji Bernas Per Buah pada Perlakuan Dosis Pupuk NPK

Berdasarkan Gambar 7 perlakuan dosis pupuk NPK 220 g/tanaman cenderung menghasilkan jumlah biji bernas paling tinggi yaitu 851,25 butir per buah. Namun, secara umum perlakuan dosis pupuk NPK memberikan pengaruh berbeda tidak nyata terhadap parameter jumlah biji per buah. Jumlah biji bernas tanaman terung Re-cycle polinasi lebih rendah dari jumlah biji bernas tanaman utama. Hal ini diduga unsur hara yang diberikan berkaitan erat dengan keberhasilan polinasi. Tanaman yang kebutuhan unsur haranya terpenuhi memiliki tingkat keberhasilan polinasi lebih tinggi dibandingkan dengan tanaman yang tidak memiliki ketersediaan unsur hara yang cukup. Dalam pembentukan buah dan biji unsur yang dibutuhkan adalah unsur $\mathrm{P}$ dan $\mathrm{K}$ seperti yang dijelaskan oleh Lingga \& Marsono, (2010) fungsi fosfor adalah untuk mempercepat pembungaan, pematangan biji dan pemasakan buah, kalium berfungsi memperkuat tanaman agar daun, bunga dan buah tidak mudah gugur. Namun, apabila dalam proses polinasi tanaman mendapatkan unsur $\mathrm{N}$ yang berlebihan maka keberhasilan dari proses polinasi akan semakin rendah, karena fungsi utama nitrogen untuk pertumbuhan dan perkembangan fase vegetatif dan akan memperlambat pertumbuhan dan perkembangan fase generative (Lingga \& Marsono, 2010).

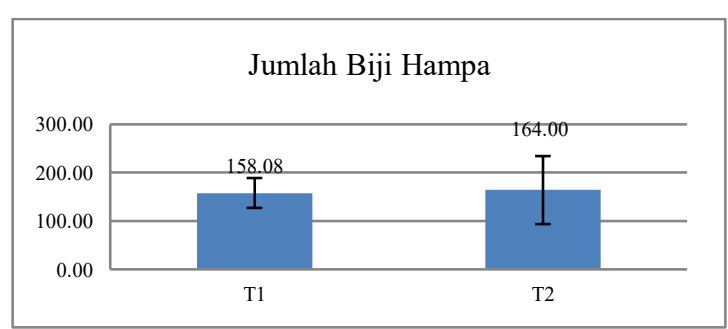

Gambar 8. Rerata Jumlah Biji Hampa Per Buah Perlakuan Teknik Pemangkasan

Berdasarkan Gambar 8 perlakuan teknik pemangkasan dengan menyisakan 3 ruas di atas cabang $\mathrm{Y}\left(\mathrm{T}_{2}\right)$ cenderung menghasilkan jumlah biji hampa lebih tinggi yaitu 164 butir per buah. Namun, secara umum perlakuan teknik pemangkasan memberikan pengaruh berbeda tidak nyata terhadap parameter jumlah biji hampar per buah. Hal ini diduga 
jumlah biji hampa setiap buah juga dipengaruhi oleh tingkat keberhasilan dalam proses pembuahan, dimana pembuahan yang sempurna akan menghasilkan biji bernas dan sebaliknya pembuahan yang tidak sempurna akan menghasilkan biji hampa. Proses pembuahan didukung oleh kondisi putik dan benang sari yang kompatibel. Serbuk sari dari benang sari akan menempel di kepala putik dan akan terus tumbuh (berkecambah) melalui tube dalam mencapai peleburan dengan sel ovum dalam pembentukan benih. Darjanto \& Satifah, (1984) menjelaskan bahwa proses pembuahan akan berlangsung optimal apabila serbuksari atau pollen dan kepalaputikharus dalam keadaan sehat dan subur. Serbuk sari harus mempunyai viabilitas atau daya berkecambah tinggi dan kepala putik harus menjadi medium yang baik untuk perkecambahan dan pertumbuhan serbuksari.

Tabel 6. Rerata Jumlah Biji Hampa pada Perlakuan Dosis Pupuk NPK

\begin{tabular}{ll}
\hline Dosis NPK & $\begin{array}{l}\text { Jumlah Biji } \\
\text { Hampa }\end{array}$ \\
\hline $120 \mathrm{~g} /$ tanaman & $175,13 \mathrm{a}$ \\
$170 \mathrm{~g} /$ tanaman & $151,13 \mathrm{a}$ \\
$220 \mathrm{~g} /$ tanaman & $156,88 \mathrm{~b}$ \\
\hline Nilai BNT \% & 1,10
\end{tabular}

Keterangan :

Angka-angka yang diikuti oleh huruf yang berbeda menunjukkan berbedan yata pada uji BNT 5\%.

Perlakuan dosis pupuk NPK 120 g/tanaman menghasilkan jumlah biji hampa paling tinggi yaitu 175,13 butir per buah. Hal ini diduga unsur fosfor dalam pupuk NPK 120 g/tanaman belum memenuhi kebutuhan unsur hara terung Re-cycle polinasi. Unsur hara yang dibutuhkan dalam pembentukan biji adalah unsur P seperti yang dijelaskan oleh Lingga $\&$ Marsono, (2010) fungsi unsur fosfor (P) adalah untuk mempercepat pembungaan, pemasakan biji, dan pemasakan buah.

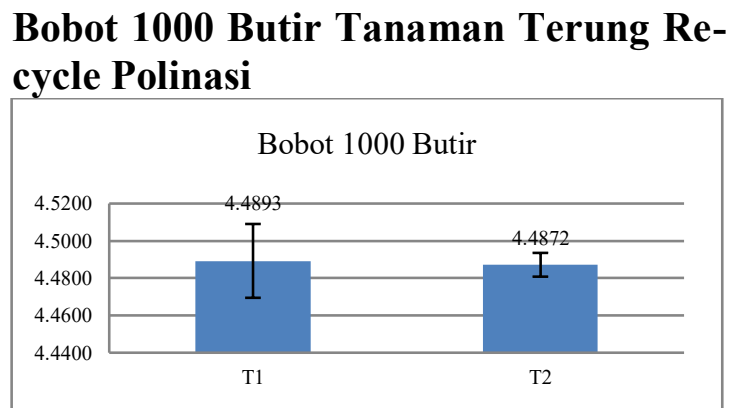

Gambar 9. Rerata Bobot 1000 Butir pada Perlakuan Teknik Pemangkasan

Berdasarkan Gambar 9, teknik pemangkasan dengan menyisakan 2 ruas di atas cabang $\mathrm{Y} \quad\left(\mathrm{T}_{1}\right)$ cenderung menghasilkan bobot 1000 butir lebih tinggi. Namun, secara umum perlakuan teknik pemangkasan memberikan pengaruh berbeda tidak nyata terhadap parameter bobot 1000 butir. Hal ini diduga karena bobot 1000 butir dapat dipengaruhi oleh bentuk dan ukuran benih. Mugnisjah \& Setiawan, (1990) menyatakan bahwa rata-rata bobot biji sangat ditentukan oleh bentuk dan ukuran biji pada suatu varietas. Lebih lanjut Ismunadji et al., (1988) menambahkan bahwa apabila tidak terjadinya perbedaan pada ukuran biji maka yang berperan adalah faktor genetik.

Tabel 7. Rerata Bobot 1000 Butir pada Perlakuan Dosis Pupuk NPK (P)

\begin{tabular}{ll}
\hline Dosis NPK & $\begin{array}{l}\text { Bobot 1000 Butir } \\
\text { (gram) }\end{array}$ \\
\hline $120 \mathrm{~g} /$ tanaman & $4,4838 \mathrm{a}$ \\
$170 \mathrm{~g} /$ tanaman & $4,4854 \mathrm{a}$ \\
$220 \mathrm{~g} /$ tanaman & $4,4955 \mathrm{~b}$ \\
\hline Nilai BNT \% & 0,0090 \\
\hline
\end{tabular}

Keterangan :

Angka-angka yang diikuti oleh huruf yang berbeda menunjukkan berbedan yata pada uji BNT 5\%.

Berdasarkan Tabel 7 dosis pupuk NPK 220 g/tanaman $\left(\mathrm{P}_{3}\right)$ menunjukkan bobot 1000 butir paling tinggi dan dosis pupuk NPK $120 \mathrm{~g} /$ tanaman menunjukkan bobot 1000 butir paling rendah. Hal tersebut diduga ketersediaan unsur $\mathrm{P}$ dalam 
pupuk NPK dapat meningkatkan bobot 1000 butir. Fosfor merupakan penyusun fosfolipid, nukleoprotein dan fitin yang selanjutnya tersimpan di dalam biji. Fosfor sangat berperan aktif mentransfer energi di dalam sel, juga berfungsi untuk mengubah karbohidrat sehingga berat 1000 butir meningkat. Hal ini sesuai dengan pernyataan Hamidah, (2013) bahwa unsur $\mathrm{P}$ dapat mendorong pertumbuhan bunga dan biji, memperbesar persentase terbentuknya bunga menjadi biji, dan membuat biji menjadi lebih bernas atau berisi.

\section{Produksi Benih Per hektar Tanaman Terung Re-cycle Polinasi}

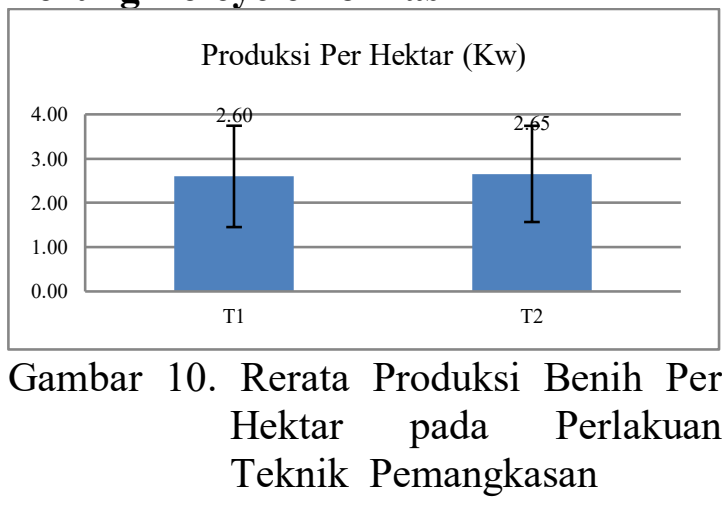

Berdasarkan Gambar 10 teknik pemangkasan dengan menyisakan 3 ruas di atas cabang $\mathrm{Y} \quad\left(\mathrm{T}_{2}\right)$ cenderung menghasilkan produksi benih per hektar paling tinggi. Namun, secara umum perlakuan teknik pemangkasan memberikan pengaruh berbeda tidak nyata terhadap parameter produksi benih terung Re-cycle polinasi. Hal tersebut diduga produksi benih per hektar dipengaruhi faktor genetik dan lingkungan. Gardner et al., (1988) menyatakan bahwa proses pembungaan, pembuahan serta pengisian biji dikendalikan oleh faktor genetik yang dipengaruhi oleh kondisi lingkungan. Faktor genetik berkaitan dengan kemampuan tanaman terung dalam mengoptimalkan produksi dalam pengaturan pengisian biji dengan mengalokasikan hasil fotosintesis secara tepat, sedangkan faktor lingkungan berhubungan dengan proses fotosintesis yaitu penyerapan unsur hara, air dan cahaya.

Berdasarkan Tabel 8 dosis pupuk NPK 170 g/tanaman menghasilkan produksi benih per hektar paling tinggi yaitu 2,85 kwintal per hektar. Hal tersebut diduga dosis pupuk NPK $170 \mathrm{~g} /$ tanaman merupakan dosis yang optimal untuk pertumbuhan dan perkembangan tanaman terung Re-cycle polinasi, sehingga dapat menyediakan sejumlah unsur hara yang diperlukan tanaman.

Tabel 8.Rerata Produksi Per Hektar pada Perlakuan Dosis Pupuk NPK

\begin{tabular}{ll}
\hline Dosis NPK & $\begin{array}{l}\text { Produksi Per Hektar } \\
(\mathrm{Kw})\end{array}$ \\
\hline $120 \mathrm{~g} / \operatorname{tanaman}$ & $2,31 \mathrm{a}$ \\
$170 \mathrm{~g} / \operatorname{tanaman}$ & $2,85 \mathrm{~b}$ \\
$220 \mathrm{~g} / \operatorname{tanaman}$ & $2,71 \mathrm{~b}$ \\
\hline Nilai BNT\% & 0,39 \\
\hline Keterangan : & \\
Angka-angka yang diikuti oleh huruf yang berbeda \\
menunjukkan berbedan yata pada uji BNT 5\%.
\end{tabular}

Huruna dan Maruapey, (2015) menyatakan bahwa unsur Nitrogen $(\mathrm{N})$ berperan dalam mempercepat pengubahan karbohidrat menjadi protein yang berpengaruh pada pembelahan, pemanjangan, dan pembesaran sel baru sehingga mempercepat pembuahan. Ketersediaan unsur hara Fosfor $(\mathrm{P})$ dalam pupuk akan mempercepat pembungaan, dan pemasakan buah atau biji yang terlihat dari jumlah buah yang terbentuk, sedangkan unsur Kalium (K) membantu meningkatkan kualitas hasil berupa bunga, buah, rasa dan warna menghasilkan karbohidrat dan protein yang berguna untuk pertumbuhan buah, sehingga dapat mempengaruhi pembesaran ukuran berat buah dan diameter buah. Hasil produksi benih per hektar tanaman terung Re-cycle polinasi lebih rendah dari hasil produksi tanaman utama. Hal tersebut diduga 
keadaan lingkungan sangat berpengaruh pada saat penelitian, dimana saat musim hujan tanaman terung memasuki fase berbunga, keadaan tersebut dapat menghambat proses polinasi atau penyerbukan. Astuti (2010) menyatakan bahwa proses penyerbukan dapat terganggu oleh intensitas curah hujan yang tinggi, sehingga dapat mengurangi hasil tanaman. Hasil produksi tanaman utama yaitu 5,09 kwintal per hektar atau 61,08 $\mathrm{g} /$ tanaman dan hasil produksi benih terung Re-cycle polinasi yaitu 2,85 kwintal per hektar atau 34,20 g/tanaman, sehingga dengan penerapan teknologi Re-cycle polinasi dapat meningkatan produksi benih terung sebesar $60 \%$ dalam satu kali penanaman.

\section{Uji Mutu Benih Tanaman Terung Re- cycle Polinas}

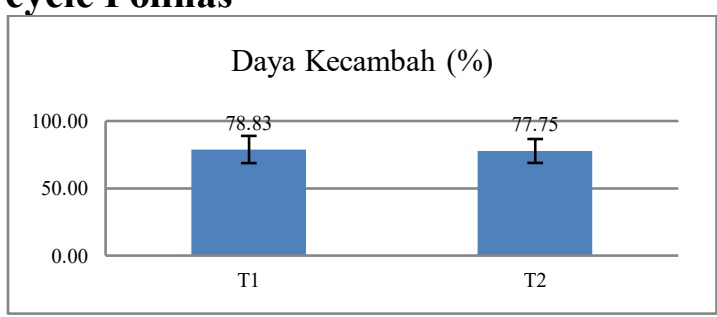

Gambar 11. Rerata Daya Kecambah pada Perlakuan Teknik Pemangkasan

Teknik pemangkasan dengan menyisakan 2 ruas di atas cabang $\mathrm{Y}\left(\mathrm{T}_{1}\right)$ cenderung menghasilkan daya kecambah lebih tinggi yaitu 78,83\% (Gambar 11). Namun, secara umum perlakuan teknik pemangkasan memberikan pengaruh berbeda tidak nyata terhadap parameter daya kecambah benih. Hal ini diduga karena daya kecambah benih tidak dipengaruhi oleh teknik pemangkasan, daya kecambah benih lebih dipengaruhi oleh ukuran benih. Sutopo, (2002) menyatakan bahwa ukuran benih menjadi salah satu faktor yang mempengaruhi proses perkecambahan pada benih karena ukuran benih menggambarkan cadangan makanan yang tersimpan dalam benih.
Pada saat proses perkecambahan cadangan makanan tersebut digunakan sebagai bahan baku dan energi bagi embrio.

Tabel 9. Rerata Daya Kecambah Benih pada Perlakuan Dosis Pupuk NPK

\begin{tabular}{ll} 
Dosis NPK & $\begin{array}{l}\text { Daya Kecambah Benih } \\
(\%)\end{array}$ \\
\hline $120 \mathrm{~g} /$ tanaman & $76,25 \mathrm{a}$ \\
$170 \mathrm{~g} /$ tanaman & $78 \mathrm{a}$ \\
$220 \mathrm{~g} /$ tanaman & $80,63 \mathrm{~b}$ \\
\hline Nilai BNT \% & 2,63 \\
\hline
\end{tabular}

Keterangan :

Angka-angka yang diikuti oleh huruf yang berbeda menunjukkan berbedan yata pada uji BNT 5\%.

Berdasarkan Tabel 9 dosis pupuk NPK $220 \mathrm{~g} /$ tanaman menghasilkan daya kecambah benih paling tinggi yaitu $80,63 \%$ dan perlakuan dosis pupuk NPK $120 \mathrm{~g} /$ tanaman menghasilkan daya kecambah paling rendah yaitu $76,25 \%$. Hal tersebut diduga karena perlakuan dosis pupuk NPK $220 \mathrm{~g} /$ tanaman merupakan dosis yang optimal bagi tanaman sehingga dapat menyediakan sejumlah unsur hara untuk pembentukan biji dengan ukuran biji yang lebih besar atau bernas. Biji atau benih yang bernas memiliki cadangan makanan yang cukup sehingga dapat menghasilkan daya kecambah yang baik.

Sutopo, (2002) yang menyatakan bahwa benih yang berukuran besar memiliki cadangan makan yang lebih banyak yang diperlukan benih sebagai energi untuk melakukan perkecambahan.

Perlakuan teknik pemangkasan dengan menyisakan 2 ruas di atas cabang $\mathrm{Y}$ $\left(\mathrm{T}_{1}\right) \quad$ cenderung menghasilkan keserempakan tumbuh benih lebih tinggi yaitu 69,83\%. Namun, secara umum perlakuan teknik pemangkasan memberikan pengaruh berbeda tidak nyata terhadap parameter keserempakan tumbuh benih. 


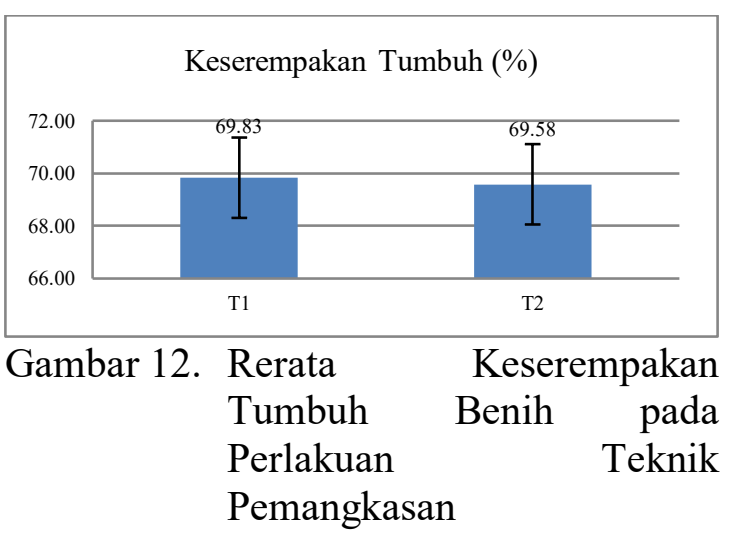

Hal tersebut diduga keserempakan benih dipengaruhi oleh ketersediaan makanan dalam benih. Perkecambahan pada benih terdiri dari beberapa tahapan yaitu terjadinya pembelahan sel, pembesaran sel dan pembagian sel-sel tersebut ke titik tumbuh, dimana proses tersebutdipengaruhi oleh cadangan makanan yang terdapat dalam biji (Sutopo, 2002).

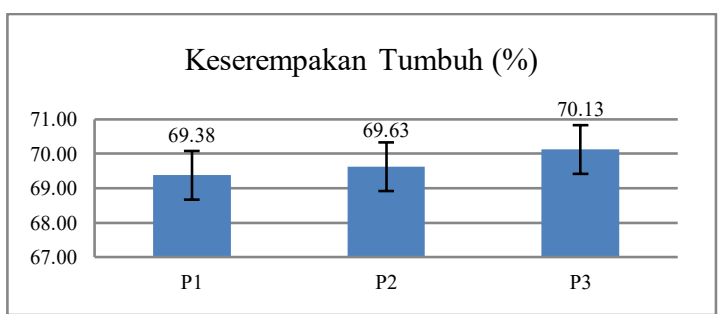

Gambar 13.Rerata Keserempakan Tumbuh Benih Perlakuan Dosis Pupuk NPK

Dosis pupuk NPK $220 \mathrm{~g} /$ tanaman cenderung menghasilkan keserempakan tumbuh benih paling tinggi yaitu 70,13\%. Namun, secara umum perlakuan dosis pupuk NPK memberikan pengaruh berbeda tidak nyata terhadap parameter keserempakan tumbuh benih terung Recycle polinasi. Ketersediaan hara yang cukup pada saat memasuki fase generative sangat mempengaruhi proses pembentukan cadangan makanan benih yang akhirnya akan mempengaruhi mutu benih. Benih yang memiliki vigor yang tinggi akan lebih serempak berkecambah sehingga dapat tumbuh serempak di lingkungan optimum maupun lingkungan sub optimum.

Pemangkasan dengan menyisakan 2 ruas di atas cabang $\mathrm{Y}\left(\mathrm{T}_{1}\right)$ tidak berpengaruh terhadap parameter kecepatan tumbuh benih. Ichsan, (2006) menyatakan bahwa komposisi akhir yang terkandung dalam benih dipengaruhi oleh proses metabolisme selama masa pematangan biji, komposisi dalam benih akan mempengaruhi proses katabolisme dan anabolisme pada saat perkecambahan. Keadaan ini pada akhirnya akan mempengaruhi viabilitas dan vigor benih padi yang diuji. Semakin tinggi nilai persentase per etmal, semakin baik vigor benih tersebut.

\section{KESIMPULAN}

Dari hasil dan pembahasan dapat disimpulkan sebagai berikut:

1. Perlakuan teknik pemangkasan pada Re-cycle polinasi hanya memberikan pengaruh nyata terhadap parameter pengamatan jumlah tunas. Teknik pemangkasan dengan menyisakan 3 ruas di atas cabang $\mathrm{Y} \quad\left(\mathrm{T}_{2}\right)$ menghasilkan jumlah tunas tertinggi yaitu 11,83 tunas.

2. Perlakuan dosis pupuk NPK berpengaruh nyata terhadap parameter umur panen, jumlah buah, bobot 1000 butir dan produksi benih per hektar, serta memberikan pengaruh yang sangat nyata pada parameter pengamatan jumlah tunas, umur berbunga, jumlah biji hampa perbuah dan daya kecambah benih hasil Recycle polinasi. Dosis pupuk NPK 170 $\mathrm{g} / \operatorname{tanaman}\left(\mathrm{P}_{2}\right)$ menghasilkan produksi per hektar tetinggi yaitu $2,7148 \mathrm{kw} / \mathrm{ha}$.

3. Tidak terdapat interaksi antara teknik pemangkasan dan dosis pupuk NPK terhadap produksi dan mutu benih terung hasil Re-cycle polinasi. 
DAFTAR PUSTAKA

Astuti, D. N. (2010). Pengaruh Sistem 尌 Pengairan Terhadap Pertumbuhan Dan Produktivitas Beberapa Varietas Padi Sawah (Oryza Sativa L.) (Thesis). Institut Pertanian Bogor.

Bukhari. (2013). Pengaruh Pemberian

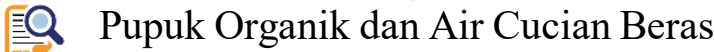
terhadap Pertumbuhan dan Hasil Tanaman Terung (Solanum melongena L.). Sains Riset, 3(1), 18.

Cahyono, E. A., Ardian, \& Silvina, F. 琶 (2014). Pengaruh Pemberian Beberapa Dosis Pupuk NPK terhadap Pertumbuhan Berbagai Sumber Tunas Tanaman Nanas (Ananas comosus L. Merr) yang Ditanam Antara Tanaman Sawit Belum Menghasilkan di Lahan Gambut. Jom Faperta, 1(2), 1-13.

Darjanto, \& Satifah, S. (1984). 尌 Pengetahuan Dasar Biologi Bunga dan Teknik Penyerbukan Silang Buatan. Jakarta: Gramedia.

Direktorat Jenderal Hortikultura. (2015).

Statistik Produksi Hortikultura Tahun 2014. Jakarta: Kementerian Pertanian.

Feleafel, M. N., \& Mirdad, Z. M. (2013).

县 Optimizing the nitrogen, phosphorus and potash fertigation rates and frequency for eggplant in arid regions. International Journal of Agriculture and Biology, 15(4).

Gardner, F. P., Pearce, R. B., \& Mitchell, 尌 R. L. (2017). Physiology of Crop Plants. Scientific publishers.

Hamidah. (2013). Efek Penggunaan Pupuk

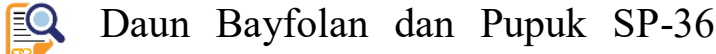

Terhadap Pertumbuhan dan Hasil Tanaman Melon (Cucumis melo L.) Varietas Action 434. Agrifor, 12(2), 148-155. https://doi.org/10.31293/ af.v12i2.344

Huruna, B., \& Maruapey, A. (2015). EQ Pertumbuhan Dan Produksi Tanaman Terung (Solanum melongena L.) Pada Berbagai Dosis Pupuk Organik Limbah Biogas Kotoran Sapi. Agroforesti, 10(3), 218-226.

Ichsan, C. N. (2006). Uji Viabilitas dan Elar Venih Beberapa Varietas Padi (Oryza sativa L.) yang Diproduksi pada Temperatur yang Berbeda Selama Kemasakan. Floratek, 2(1), 37-42. https://doi.org/10.24815/ floratek.v2i1.70

Ismunadji, M., Prataharjana, S., Syamdan, 㳑 M., \& Wdjono, A. (1988). Padi. Bogor: Pusat Penellitian dan Pengembangan Tanaman Pangan.

Lingga, P., \& Marsono. (2010). Petunjuk 嘼 Penggunaan Pupuk. Jakarta: Penebar Swadaya.

Mugnisjah, W. Q., \& Setiawan, A. (1990). 尌 Pengantar Produksi Benih. Bogor: Rajawali Pers.

Pujisiswanto, H., \& Pangaribuan, D. (2008). Pengaruh dosis kompos pupuk kandang sapi terhadap pertumbuhan dan produksi buah tomat. In Prosiding Seminar Nasional Sains dan Teknologi-II (pp. 17-18). Universitas Lampung.

Raden, I., Purwoko, B. S., Hariyadi, EQ Ghulamahdi, M., \& Santosa, E. (2009). Pengaruh Tinggi Pangkasan Batang Utama dan Jumlah Cabang Primer yang Dipelihara terhadap 
Produksi Minyak Jarak Pagar (Jatropha curcas L.). Jurnal Agronomi Indonesia, 37(2), 159166. https://doi.org/10.24831/jai. v37i2.1409

Rina, D. (2015). Manfaat Unsur N, P dan 镀 K Bagi Tanaman. Retrieved from http://kaltim.litbang.pertanian.go.id/ ind/index.php?option $=$ com_content $\&$ view $=$ article $\& \mathrm{id}=707 \&$ Itemid $=59$

Seran, R. N. (2016). Effect of pruning of 佥 lateral budding and flower on eggplant (Solanum melongena L.) growth and yield. Savana Cendana, 1(02), 93-97. https://doi.org/ 10.32938/sc.vli02.20

Sholeh, M., \& Djumali. (2008). Pengaruh 住 pertumbuhan dan hasil tanaman jarak pagar (Jatropha curcas L.). In Lokakarya Nasional III Inovasi Teknologi Jarak Pagar untuk Mendukung Program Desa Mandiri Energi (pp. 219-223). Bogor: Institut Pertanian Bogor.

Soetasad, A. A., \& Muryanti, S. (2000). 尌 Budidaya Terung Lokal dan Terung Jepang. Jakarta: Penebar Swadaya.

Sutopo, L. (2002). Teknologi Benih. 尌 Jakarta: Raja Grafindo Persada. 